\begin{tabular}{cc}
\hline$J C E B T, 1$ (1) Maret 2017 $\quad$ ISSN 2549-6379 (Print) & ISSN 2549-6387 (Online) \\
JCEBT & \\
Oournal of Civil Engineering, Building and Transportation) \\
Available online http://ojs.uma.ac.id/index.php/jcebt
\end{tabular}

\title{
Pemanfaatan Limbah Styrofoam dan Serat Sabut Kelapa sebagai Bahan Tambah Genteng Beton
}

\section{Utilization of Styrofoam Waste and Coco Fiber Fiber as Added Concrete Tile Material}

\author{
Fauziah Dwi Astuti, Edy Hermanto*, Kamaluddin Lubis \\ Program StudiTeknik Sipil, FakultasTeknik, Universitas Medan Area, Indonesia \\ *Coresponding Email: edyhermanto2@gmail.com
}

\begin{abstract}
Abstrak
Semakin pesatnya pembangunan yang dilakukan maka sangat dibutuhkan bahan penutup atap yang baik dan memenuhi persyaratan kuat, ringan, dan kedap air. Perbandingan antara semen portland, kapur mill, dan pasir pada komposisi campuran genteng beton yaitu 1 PC : 3 PS. Sedangkan persentase penambahan serat sabut kelapa dan styrofoam $0 \% ; 10 \%$; 15\%; 40\% dari berat volume pasir. Analisis data dilakukan dengan menghitung rata-rata hasil pengujian kemudian dibandingkan dengan persyaratan SNI 0096-2007. Hasil pengujian ketahanan terhadap rembesan (impermeabilitas) genteng beton dengan penambahan serat sabut kelapa dan styrofoam $0 \% ; 10 \% ; 15 \% ; 40 \%$; semuanya tidak terjadi rembesan, hasil pengujian penyerapan air (porositas) rata-rata genteng beton pada penambahan serat sabut kelapa dan styrofoam $0 \%=4,40 \% ; 10 \%=4,28 \% ; 15 \%=6,89 \% ; 40 \%=7,32 \%$; Hasil pengujian beban lentur rata-rata pada persentas penambahan serat sabut kelapa dan styrofoam $0 \%=150,3 \mathrm{~kg} ; 10 \%=177,8 \mathrm{~kg} ; 15 \%=191,7 \mathrm{~kg} ; 40 \%=223.5 \mathrm{~kg}$. Dari hasil pengujian tersebut maka dapat disimpulkan bahwa semakin banyak persentase serat yang ditambahkan dalam genteng beton maka semakin besar beban lentur yang dihasilkan. Hasil penelitian menunjukkan bahwa genteng beton dengan penambahan serat sabut kelapa sudah memenuhi SNI 0096-2007 dari segi ketahanan terhadap rembesan (impermeabilitas), sebagian porositas, sifat tampak, dan ukuran.
\end{abstract}

Kata Kunci: Genteng Beton, Serat Sabut Kelapa, Styrofoam.

\begin{abstract}
The more rapid development is done, it is needed a good roof covering material and meet the requirements of strong, lightweight, and watertight. Comparison between portland cement, lime mill, and sand on the composition of concrete tile mix is 1 PC: 3 PS. While percentage of coco fiber and styrofoam addition 0\%; $10 \% ; 15 \% ; 40 \%$ by weight of sand volume. Data analysis is done by calculating the average of test result then compared with requirement of SNI 0096-2007. Test results of resistance to seepage (impermeability) of concrete roof tile with the addition of coco fiber and styrofoam 0\%; 10\%; 15\%; 40\%; all seepage did not occur, the result of water absorption test (porosity) average of concrete roof tiles on the addition of coco fiber and styrofoam $0 \%=4.40 \% ; 10 \%=4.28 \% ; 15 \%=6.89 \% ; 40 \%=7.32 \%$; The average bending load test results on the percentage of coco fiber and styrofoam $0 \%=150,3 \mathrm{~kg} ; 10 \%=177.8 \mathrm{~kg} ; 15 \%=191.7 \mathrm{~kg}$; $40 \%=223.5 \mathrm{~kg}$. From the test results it can be concluded that the more percentage of fiber added in concrete roof tiles the greater the resulting flexible bending. The results showed that the concrete roof tile with the addition of coco fiber has fulfilled SNI 0096-2007 in terms of resistance to seepage (impermeability), partial porosity, visible properties, and size.
\end{abstract}

Keywords: Concrete Tile, Coconut Fiber Fiber, Styrofoam.

How to Cite: Astuti, F.A. Hermanto, E. Lubis, K. (2017). Pemanfaatan Limbah Styrofoam dan Serat Sabut Kelapa sebagai Bahan Tambah Genteng Beton. JCEBT (Journal of Civil Engineering, Building and Transportation). 1 (1): 1118 
Fauziah Dwi Astuti, Edy Hermanto*, Kamaluddin Lubis. Pemanfaatan Limbah Styrofoam dan Serat Sabut

\section{PENDAHULUAN}

Atap adalah bagian dari bangunan yang berfungsi sebagai pelindung rangka atap atau secara keseluruhan terhadap pengaruh cuaca seperti panas, hujan, angin. Adapun persyaratan penutup atap yang baik adalah awet, kuat dan tahan lama. Dengan banyaknya gedung - gedung yang dibangun maka sangat dibutuhkan bahan penutup atap yang baik, yaitu penutup atap yang memnuhi persyaratan kuat, ringan, dan kedap air, kedap suara. Genteng beton merupakan salah satu penutup atap yang baik, namun tidak banyak masyarakat yang menggunakan genteng beton, selain harganya relative mahal bila dibandingkan dengan genteng lain, genteng beton juga termasuk penutup atap yang berat, sehingga memerlukan konstruksi rangka atap yang kuat agar dapat menahan berat genteng beton tersebut yang mengakibatkan konstruksi rangka lebih kokoh dan mahal.

Maksud dari penelitian ini adalah untuk merancang dan menciptakan inovasi baru genteng beton yang telah memenuhi kriteria - kriteria sebagai atap yang dapat melindungi bangunan yang ada dibawahnya dengan memiliki keunggulan yaitu kuat namun ringan, harga terjangkau oleh masyarakat serta ramah lingkungan.

Sedangkan tujuan dari penelitian ini adalah untuk memanfaatkan limbah
Styrofoam dan serat sabut kelapa yang terbuang sebagai bahan campuran dalam pembuatan genteng beton yang ringan. Dan diharapkan dalam penelitian ini mampu sedikitnya mengurangi limbah yang terbuang diluar dan dapat di manfaatkannya sebagai bahan tambahan pada genteng beton. Berapa nilai variasi prensentasi Styrofoam dan sabut kelapa yang akan dipergunakan dalam pembuatan genteng beton.

\section{METODE PENELITIAN}

Pelaksanaan pembuatan benda uji dan pengujian genteng beton serat dilakukan di pabrik genteng beton Mulia di jalan Gatot Subroto, Medan, Sumatera Utara. Adapun pengujian yang akan dilakukan adalah pengujian kuat lentur, penyerapan air (porositas), dan ketahanan terhadap rembesan air (impermeabilitas). Rancangan penelitian yang digunakan adalah metode eksperimen yang merupakan metode penelitian yang digunakan untuk mencari pengaruh treatment (perlakuan) tertentu.

Metode pengumpulan data merupakan instrument yang merupakan keberhasilan suatu penelitian. Oleh karena itu dalam menentukan metode yang digunakan harus benar-benar sesuai dengan jenis-jenis data yang akan diselidiki. Secara garis besar data yang 
akan diselidiki dalam penelitian ini berupa kuat lentur, rembesan air (impermeabilitas) dan penyerapan air (porositas).

\section{Bagan Alur Penelitian}

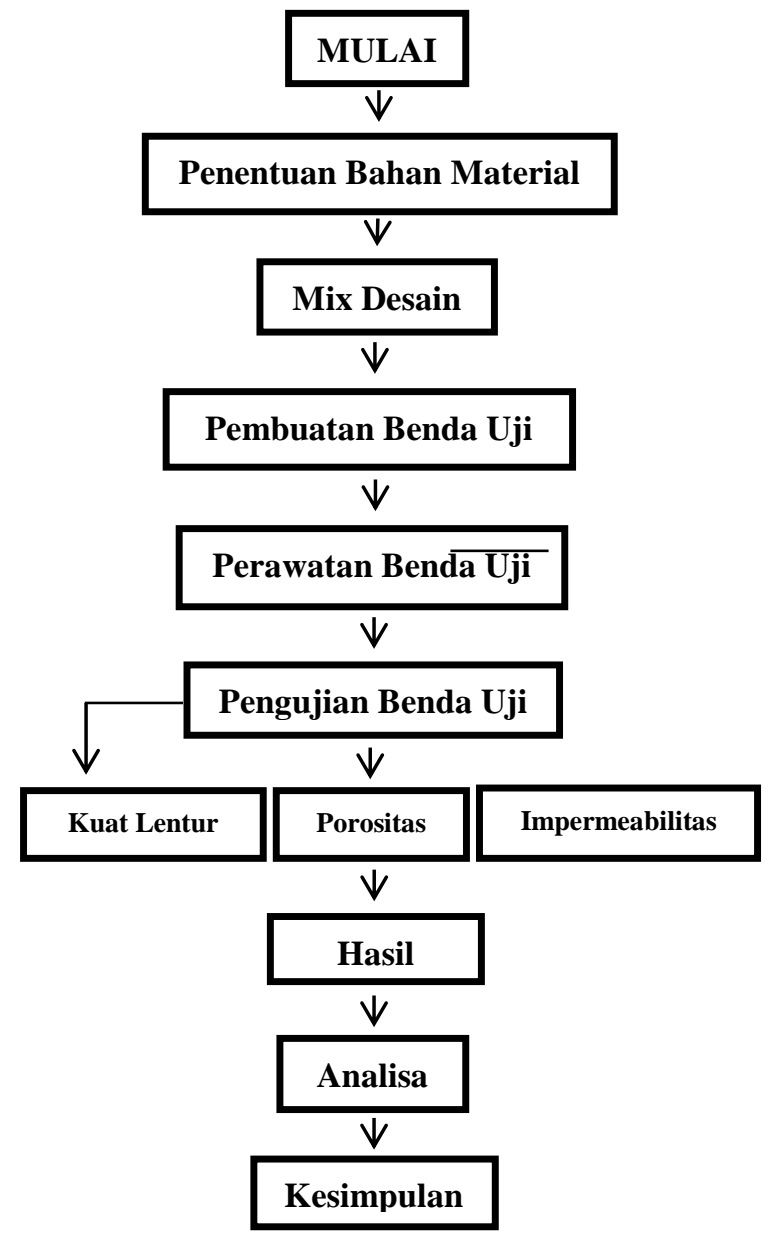

Gambar 3. BaganAlurPenelitian

Bahan yang digunakan dalam penelitian ini yaitu Semen yang dipakai adalah semen portland merk Andalas dengan kemasan 40 kg. Pasir yang digunakan adalah pasir yang digunakan di dalam lokasi pabrik. Air yang digunakan dalam pembuatan genteng beton ini adalah air yang berada ditempat pembuatan dan pengujian sempel. Serat Sabut Kelapa yang sudah bersih dan berbentuk serat dengan persentase $0 \% ; 10 \% ; 15 \%, 4 \quad 0 \%$ dan terhadap pengurangan volume pasir.

Peralatan yang digunakan dalam penelitian ini baik pembuatan sempel dan pengujian sempel antara lain Ayakan yang digunakan adalah ayakan yang dipergunakan pada pabrik tersebut. Jangka sorong digunakan untuk pengujian ukuran genteng beton yang telah jadi. Timbangan kodok, dengan ketelitian 1 gram digunakan untuk mengukur berat sempel kurang dari $20 \mathrm{~kg}$. Mesin Uji Beban Lentur Digunakan untuk menguji kuat lentur genteng beton. Oven Digunakan untuk mengoven benda uji/sampel. Meteran ini digunakan untuk mengukur panjang dan lebar genteng beton. Lilin/malam Digunakan untuuk perekat antara seng dan genteng beton dalam pengujian rembesan air (impermeabilitas). Bak perendam digunakan untuk merendam genteng beton yang sudah dikeringkan selama 24 jam, dengan lama perendaman minimal 14 hari.

Proses pembuatan benda uji, adalah sebagai berikut:

\section{Tahap Persiapan}

Persiapan pasir yang akan digunakan, pasir yang digunakan adalah pasir yang dipergunakan di pabrik. Persiapan semen portland yang akan digunakan, yaitu dengan memeriksa apakah semen dalam kondisi halus tidak menggumpal. Semen 
Fauziah Dwi Astuti, Edy Hermanto*, Kamaluddin Lubis. Pemanfaatan Limbah Styrofoam dan Serat Sabut

yang digunakan adalah semen Andalas dengan kemasan $40 \mathrm{~kg}$.

\section{Perencanaan Kebutuhan Bahan}

\section{Benda Uji}

Dalam penelitian ini, telah ditetapkan memakai perbandingan pc: ps $=1: 3$. Selanjutnya perbandingan ini dikonversikan ke dalam perbandingan volume. Hal ini dilakukan untuk mengetahui jumlah perencanaan kebutuhan bahan per adukan dalam membuat sejumlah benda uji genteng beton.

3. Pembuatan Benda Uji Genteng Beton

\section{Serat}

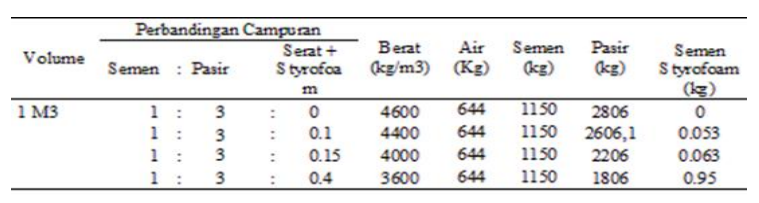

Gambar 4. Persiapan bahan penyusun genteng beton

Persiapan yang utama antara lain persiapan bahan baku genteng beton dan tempat untuk pengerjaannya. Bahan yang harus disiapkan adalah pasir, semen portland, serat sabut kelapa dan styrofoam, dan air.

Tahap pencampuran dan pengadukan bahan susun genteng beton. Bahan susun genteng beton serat (semen, pasir, dan serat sabut kelapa) dimasukkan kedalam tempat pembuatan adukan dan dicampur dalam keadaan kering dengan menggunakan cetok sampai adukan menjadi homogen, yaitu jika warnanya sudah sama.

Tahap pencetakan bahan susun genteng betonAdukan yang telah homogen, selanjutnya dituang dalam cetakan genteng beton sampai penuh yang sebelumnya telah diolesi pelumas. Lalu ditekan dan digosok-gosok sampai halus, setelah itu genteng beton yang sudah jadi diangkat ke tempat pemeliharaan.

\section{Pengeringan}

Genteng beton yang telah selesai dicetak, dikeringkan dengan ditempatkan di atas tatakan atau rak-rak, kemudian diangin-anginkan pada tempat yang terlindung dari terik matahari dan hujan selama 24 jam.

\section{Perawatan benda uji genteng beton}

Setelah proses pencetakan benda uji selesai, kemudian disimpan dalam ruangan lembab selama 24 jam dengan menggunakan tempat pengeringan genteng beton. Kemudian benda uji direndam dalam air bersih selama minimal 14 hari (dalam penelitian ini selama 14 hari), setelah itu genteng beton diangkat dari tempat perendaman dan dianginanginkan selama 1-2 hari.

\section{Pengujian Benda Uji}

a) Pengujian Kuat Lentur Genteng Beton

Genteng beton yang sudah berumur 14 hari kemudian diuji kuat lenturnya. Alat penguji terdiri dari sebuah alat uji lentur 
yang dapat memberikan beban secara teratur dan merata dengan ketelitian 0,1 kg. Penumpu dan landasan terbuat dari besi, di bawah penumpu diberi tatakan yang terbuat dari kayu dengan lebar tidak kurang dari $20 \mathrm{~mm}$ yang salah satu sisinya dibuat lekukan sesuai dengan bentuk genteng beton dan dilekatkan pada genteng beton.

b) Pengujian

Rembesan

Air hari.

(impermeabilitas) Genteng Beton.

Pengujian ini bertujuan untuk mengetahui rembesan air genteng beton dengan penambahan serat sabut kelapa dan styrofoam. Langkah-langkahnya yaitu, membuat mal berbentuk persegi panjang yang terbuat dari seng.

c) Pengujian Penyerapan Air (porositas) Genteng Beton.

Pengujian ini bertujuan untuk mengetahui penyerapan air genteng beton dengan penambahan serat sabut kelapa dan styrofoam. Langkah-langkahnya yaitu, genteng beton di oven pada suhu $110^{\circ} \mathrm{C} \pm$ $5^{\circ} \mathrm{C}$, selanjutnya ditimbang dalam keadaan kering oven, lalu genteng beton tersebut direndam dalam air selama 24 jam, kemudian genteng ditimbang dalam keadaan basah dengan mengelap permukaan genteng lebih dulu dengan lap lembab.

\section{HASIL DAN PEMBAHASAN}

Genteng beton serat merupakan genteng beton yang dibuat dengan tujuan untuk menambah kuat lentur dari genteng beton. Bahan penyusun dari genteng beton itu sendiri adalah pasir, semen, air dan ditambah serat sabut kelapa. Dalam proses pembuatannya diperlukan waktu perawatan dan pengeringan selama 14 hari.

Hasil Pemeriksaan Bahan dan Benda Uji

Air Pengujian terhadap air dilakukan dengan pengamatan secara visual sesuai dengan buku petunjuk praktek asisten teknisi laboratorium pengujian beton. Air yang digunakan terlihat tidak berwarna (jernih) dan tidak berbau.

Semen Pengujian secara visual mengenai keadaan kemasan semen yang digunakan terlihat masih baik, tidak ada cacat pada kemasan (robeknya kemasan), keadaan kemasan kering, serta keadaan semen dalam kemasan masih gembur (tidak memadat, dilakukan dengan cara memijat semen dalam kemasan).

\section{Serat Sabut Kelapa dan Styrofoam}

Serat yang digunakan dalam penelitin ini adalah serat yang sudah di bersihkan dari serbuk-serbuk kelapanya. Sedangkan Styrofoam yang digunakan adalah Styrofoam yang berukuran kecil. 


\section{Pengujian Kuat Lentur}

Pengujian beban lentur benda uji genteng beton dilakukan pada umur 14 hari dengan jumlah benda uji 10 buah untuk masing-masing variabel penambahan serat sabut kelapa dan styrofoam dan pengurangan pasir 0\%; $10 \% ; 15 \%$ dan $40 \%$.

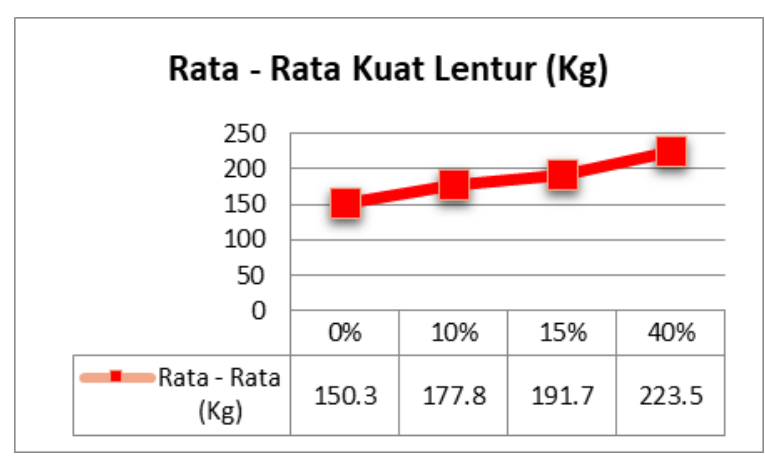

Gambar 5. Rata-Rata KuatLentur

\section{Pengujian}

\section{(impermeabilitas)}

Pengujian

rembesan

\section{Rembesan} Air air (impermeabilitas) benda uji genteng beton dilakukan pada umur 14 hari dengan jumlah benda uji 10 buah untuk masingmasing variabel penambahan serat sabut kelapa dan styrofoam dan pengurangan pasir 0\%; 10\%; 10\%; 15\% dan 40\%.

\section{Pengujian Penyerapan Air (porositas)}

Pengujian penyerapan air (porositas) benda uji genteng beton dilakukan pada umur 14 hari dengan jumlah benda uji 10 buah untuk masing-masing variabel penambahan serat sabut kelapa dan styrofoam serta pengurangan pasir 0\%; 10\%; 15\% dan 40\%.

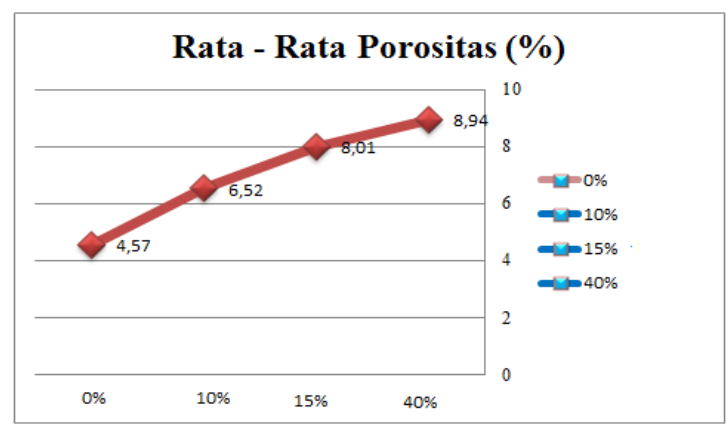

Gambar 6. Rata-Rata Porositas

\section{Pengujian Kuat Lentur}

Dalam perhitungan standard deviasi (Sd), jumlah benda uji (n) tidak dikurangi 1. Hal tersebut dikarenakan pada kajian ini hanya menggunakan tiga buah sampel, dimana jika n-1 digunakan jika jumlah sampel minimal 10 buah.

Hasil karakteristik genteng beton pada variasi $0 \%$ adalah $150.3 \mathrm{~kg}$, hasil tersebut memenuhi persyaratan sebagaimana yang tercantum dalam SNI 0096:2007, Sedangkan pada karakteristik beban lentur pada variasi 10\%; 15\% dan 40\% hasilnya berikut ini 177.8 kg; 197.5 $\mathrm{kg}$; dan $223,5 \mathrm{~kg}$.

\section{Pengujian}

\section{Rembesan}

Air

\section{(impermeabilitas)}

Pengujian ketahanan terhadap rembesan air dilakukan selama lebih dari 20 jam, dengan jumlah sampel untuk setiap variasi penambahan serat sabut kelapa dan styrofoam masing-masing 
adalah 10 buah sampel. Hasil dari pengujian impermeabilitas dengan penambahan serat sabut kelapa dan styrofoam sebesar $0 \% ; 10 \%, 15 \%$ dan $40 \%$ semuanya tidak ada tetesan air yang menetes pada permukaan bawah genteng akibat dari rembesan air.

\section{Pengujian Penyerapan Air (porositas)}

Dari hasil pengujian penyerapan air menunjukan bahwa penambahan serat sabut kelapa dan styrofoam ke dalam campuran genteng beton dapat meningkatkan beban lentur, namun menyebabkan genteng beton memiliki lebih banyak rongga atau pori.

Hasil dari pengujian porositas genteng beton dengan penambahan serat serat sabut kelapa dan styrofoam 0\%; $10 \% ; 15 \%$; dan $40 \%$ adalah sebagai berikut $4.40 \% ; 4.28 \% ; \quad 6,89 \%$ dan 7,32\%. Dengan demikian genteng beton dengan penambahan serat sabut kelapa dan styrofoam dengan persentase $0 \% ; 10 \%$; $15 \%$ dan $40 \%$ dapat digunakan sebagai bahan penutup atap pada bangunan.

\section{Bentuk dan Ukuran Genteng Beton}

Gambar di bawah ini merupakan bentuk genteng hasil dari penelitian dengan penambahan serat sabut kelapa dan styrofoam sebagai bahan subtitusi.

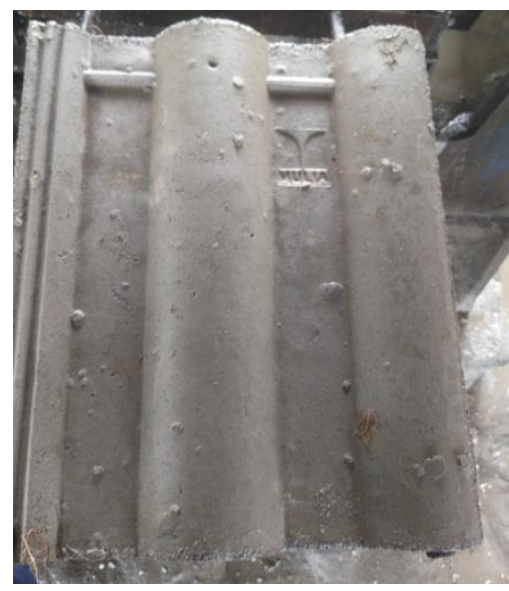

Gambar 7. Bentuk Genteng Hasil Penelitian

Selain bentuk dan ukurannya yang sama genteng beton dengan campuran sebesar $40 \%$ menghasikan genteng beton dengan kuat lentur yang paling baik yaitu $223,5 \mathrm{~kg}$, dengan berat genteng beton yang paling ringan yaitu 3600 gr.

\begin{tabular}{|c|c|c|c|c|c|}
\hline \multirow{2}{*}{ No } & \multirow{2}{*}{ Uraian } & \multicolumn{2}{|c|}{ Ukuran (Cm) } & \multirow{2}{*}{$\begin{array}{l}\text { Tebal } \\
(\mathrm{Cm})\end{array}$} & \multirow{2}{*}{$\begin{array}{l}\text { Berat } \\
(\mathrm{Gr})\end{array}$} \\
\hline & & Panjang & Lebar & & \\
\hline 1 & $\begin{array}{l}\text { Genteng hasil penelitian } \\
\text { dengan persentase } 40 \%\end{array}$ & 41 & 33 & 0.10 & 3600 \\
\hline 2 & $\begin{array}{l}\text { Genteng yang ada } \\
\text { dipasaran dengan merk } \\
\text { yang sama }\end{array}$ & 41 & 33 & 0.10 & 4650 \\
\hline
\end{tabular}

Dari keterangan tabel di atas dapat disimpulkan bahwa secara bentuk dan ukuran genteng beton dengan atau tanpa campuran serat sabut kelapa dan styrofoam tidak memiliki perbedaan.

\section{SIMPULAN}

Dari hasil penelitian dan pengujian, genteng beton dengan penambahan serat sabut kelapa dan styrofoam sebesar $40 \%$ menghasilkan kuat lentur yang paling baik yaitu 223,5 kg. Dengan hasil tersebut maka pengujian kuat lentur genteng beton serat 
Fauziah Dwi Astuti, Edy Hermanto*, Kamaluddin Lubis. Pemanfaatan Limbah Styrofoam dan Serat Sabut

memenuhi persyaratan yang ada di SNI 0096:2007 yaitu untuk genteng beton dengan tinggi profil $20 \geq \mathrm{t} \geq 5 \mathrm{~mm}$ dan lebar penutup $\geq 300 \mathrm{~mm}$ harus memiliki karakteristik beban lentur minimum 150.3 kg. Pengujian rembesan air (impermeabilitas) untuk penambahan serat sabut kelapa dan styrofoam sebesar $40 \%$ masih memenuhi standar SNI 0096:2007 yaitu tidak terjadi tetesan atau rembesan dibawah genteng. Pengujian penyerapan air (porositas) untuk penambahan serat ijuk sebesar $40 \%$ hasilnya adalah 7,32\%. Hasil tersebut masih memenuhi standard SNI 0096: 2007 yaitu penyerapan air (porositas) tidak melebihi 10\%. Dengan penambahan serat sabut kelapa dan styrofoam pada genteng beton menjadikan berat genteng beton menjadi lebih ringan. Dengan berat genteng beton sebagai berikut, untuk penambahan $0 \%$ beratnya 4650 gram; penambahan $10 \%$ beratnya 4450 gram; penamabahan $15 \%$ beratnya 4000 gram ; dan penambahan $40 \%$ beratnya 3600 gram. Untuk penelitian selanjutnya sebaiknya dicoba menggunakan persentase serat sabut kelapa dan Styrofoam yang lebih tinggi atau bervariasi tetapi campurannya tetap supaya diketahui peningkatan beban lentur yang maksimal akibat penambahan sabut kelapa dan styrofoam dengan pengurangan pasir.
Untuk penelitian selanjutnya sebaiknya dicoba menggunakan persentase serat sabut kelapa dan styrofoam yang lebih tinggi tetapi campurannya tetap untuk mengetahui ketahanan terhadap rembesan air (impermeabilitas) genteng beton.

\section{DAFTAR PUSTAKA}

Sulistiyono. (2014). Pengaruh Penambahan Serat Ijuk Sebagai Bahancampuran Dalam Pembuatan Genteng Beton. Semarang: Skripsi, Jurusan Teknik Sipil, Universitas Negeri Semarang, (UNNES.

SNI 0096-2007. Genteng Beton. Jakarta: Badan Standarisasi Nasional (BSN).

Mulyono, Tri. (2003). Teknologi Beton.Yogyakarta: Andi.

Supatmi. (2011). Analisis Kualitas Genteng Beton Dengan Bahan Tambah Serat Ijuk Dan Pengurangan Pasir. Yogyakarta: Skripsi, Jurusan Teknik Sipil, Universitas Negeri Yogyakarta, (UNY) 